\title{
Southern Republican Subnational Advancement: The Redistricting Explanation
}

\author{
Joseph A. Aistrup, Fort Hays State University
}

Implicit in numerous explanations concerning the Republicans' problems in the South is the rationale that the Democrats gerrymander away any Republican gains. However, with the enforcement of provisions of the Voting Rights Act, others have found evidence that it is the Republicans who gain from the redistricting process. This article tests these propositions by analyzing the extent of bias and the swing ratio for southern state legislative contests both before and after the 1970s and the 1980s redistricting, respectively, as well as controlling for single-member (SMD) and multimember (MMD) districts. We find that the orthodoxy described above is not strongly supported. The district lines for contested elections were not substantially biased toward the Democrats in the first place, and the bias of the representational system does not show a substantial movement toward the GOP after the switch from MMDs to SMDs. Democrats appear to benefit from redistricting as a result of a decline in the swing ratio, thus making their incumbents better protected from aggregate swings in voter preference.

This article assesses the influence of the redistricting process in the 1970 s and 1980s on the southern Republicans' ability to fairly compete for state legislative seats in ten of the 11 Confederate states (excluding Louisiana $\left.^{1}\right)$. We evaluate the influence of redistricting by charting the extent of bias toward the Democrats in southern state legislative contests and by exploring whether the elimination of multimember districts, in pursuance of the Voting Rights Act, aids the GOP's ability to win elections. This topic is significant because of the electoral success of Republicans in presidential contests juxtaposed to their anemic gains in subnational elections (Bullock 1989). Republicans like Jim Nathanson, former director of the Republican National Committee's Political Division, naturally insist that southern Democrats have stacked the institutional arrangements against them through redistricting-covertly circumventing voters' real Republican predispositions, as reflected in presidential voting patterns-away from parallel GOP gains in state legislative races. ${ }^{2}$

\section{Redistricting Process}

It is not uncommon for Republican state party chairs to rail against Democratic gerrymandering. George Strake, former chair in Texas during

JoSEPH A. AISTRuP is Assistant Professor of Political Science and Assistant Director of the Docking Institute of Public Affairs at Fort Hays State University in Hays, Kansas.

The American Review of Politics, Vol. 16, Spring, 1995: 15-32

๑1995 The American Review of Politics 
the mid-1980s, boasted that the GOP would control "ten more Congressional districts" in Texas if it were not for the Democrats controlling the redistricting process. ${ }^{3}$ Strake's remark represents just one voice in the GOP's chorus line concerning the Democratic party's atrocities in the South. For the GOP state parties, the equation is rather simple. The Democrats rig the constituency boundaries to 1) concentrate Republican strength in as few of districts as possible, 2) dilute the remaining Republican strength by partialling out favorably disposed Republican constituencies among strong Democratic constituencies, and 3 ) with the remaining jurisdictions, minimize the number of marginal Democratic districts, and maximize the number of marginal Republican districts.

From an institutional perspective, the GOP has grounds to question the nature and intention of district line boundaries. Except for the governorships in Virginia and Tennessee in 1971-72 and Arkansas, Tennessee, Texas and Virginia in 1981-82, the southern Democrats have controlled all the relevant political institutions determining district line boundaries in the 1970s and 1980s. Because Democrats possessed veto proof majorities in Virginia, Arkansas, and Texas, only Tennessee provided the Republicans with some realistic opportunity to influence district line boundaries (in both decades).

Assuming for the moment, that redistricting can alter the direction and nature of party competition (Abramowitz 1983), this Democratic domination of legislatures and governorships suggests the Republicans prospects for obtaining fair district lines is a function of Democratic altruism (an extinct emotion) or Democratic miscalculation. With the Democrats controlling the legislatures and the drawing of constituency boundaries, southern Republicans attempt to perpetuate a myth that the Democrats have complete institutional control. However, influencing redistricting in the southern states are the provisions of the Voting Rights Act (VRA) (1969), which force state legislatures to create majority black districts when feasible and to assure that black votes are not diluted (Grofman 1990).

There is much speculation in the media and by some academics (Bullock and Gaddie 1993) that these provisions of the VRA have been transformed into a Republican tool for creating representational districts that are highly susceptible to Republican activity. When black majority districts are formed and/or multimember districts (MMD) are dismantled on the basis that they dilute black votes, it generates single-member districts (SMD) that are more white, and generally "suburban". Because blacks comprise such a large segment of the Democratic power base in the South (Black and Black 1987), constructing single-member black majority districts increases the likelihood that the most reliable segment of Democratic support (blacks) will be concentrated in a smaller number of districts. These conditions create a 
large number of single-member districts that are more white, suburban, and amenable to Republican overtures (Bullock and Gaddie 1993, 156-157).

Significantly, the Reagan Justice Department, whose actions are analyzed in this paper, pursued more of a strategy oriented toward dismantling MMDs. The Reagan Justice Department, governed by the 1969 version of the Voting Rights Act, did not exclusively focus on the creation of majority black districts because it had to show "intent" to discriminate. The 1982 version of the Voting Rights Act enabled the Bush Justice Department (ten years later) to more aggressively pursue the creation of majority black districts because government lawyers only had to show that the "effect" of district line boundaries discriminated (affirmative gerrymandering). Even though the Reagan Justice Department's emphasis on this strategy was to a lesser extent, they nonetheless pursued the basic theory outlined above (Bullock and Gaddie 1993).

In states like South Carolina and Florida, this led to an increase in the number of African-American and women representatives along with an increase in the number of Republican representatives (Bullock and Gaddie 1993). Thus, even though the GOP claims with some frequency and volume that the redistricting works against their interests, the Republicans appear to have used the institutional mechanism of the VRA, to enhance the possibility for Republican partisan gain. ${ }^{4}$

In this article, we analyze the possible results of redistricting by examining two distinct components of representational districts-the swing ratio and partisan bias (Butler 1953; Tufte 1973; Grofman 1983; Campagna and Grofman 1990) - both prior to redistricting and after redistricting. We find that the Republican orthodoxy concerning redistricting is not strongly supported. Contested districts were not substantially biased toward the Democrats in the first place, and this bias remains insignificant after the switch from MMDs to SMDs. Democrats appear to benefit from redistricting as a result of a decline in the swing ratio.

\section{The Swing Ratio and Bias}

"The swing ratio measures the responsiveness of the electoral system to changes in votes" (Campagna and Grofman 1990, 1246). The measurement of the swing ratio has evolved over time. In its simplest form, it is a ratio between the change in a party's share of seats for each change in its share of votes (Jacobson 1990; Abramowitz 1983; Tufte 1973; Ansolabehere et al. 1988). ${ }^{5}$ However, this measure has been widely criticized as inadequate because it includes both the system's responsiveness to changes in votes, and the partisan bias of the system when a partisan bias is present 
(Campagna and Grofman 1990, 1247). Partisan bias "is a measure of the symmetry in the way in which each party is able to translate its votes into seats" (Campagna and Grofman 1990, 1246). It is necessary to estimate both the partisan bias and swing ratio to judge the degree of gerrymandering in redistricting.

In the case of southern Republicans, both the swing ratio and the partisan bias are important. If the system is substantially and increasingly gerrymandered against the Republicans, the bias of the system (the symmetry in which votes are translated to seats) will favor the Democratic party. More importantly, this Democratic bias will increase from the 1970s to the 1980s. At the same time, if the Democrats are mainly on the defensive and in the mode of protecting "Democratic" incumbent seats, the swing ratio will decrease from the 1970 s to the 1980 s. The Democrats will become more insulated from changes in aggregate vote share.

We measure the swing ratio and bias of the southern party system using methods based on the work of Butler (1953), Tufte (1973), Grofman (1983), and Campagna and Grofman (1990). The first step in this process is to generate a projected seats-votes relationship. This can be accomplished by uniformly changing the actual vote share by increments of plus and minus one percent, respectively, and calculating, based from the proportion of seats the party actually won, a new projection of the seats that party would win. The projected seats-votes curve is limited in this analysis to $\pm 10 \%$ of the actual seats-vote outcome. This keeps the analysis limited to the realm of what is possible (Campagna and Grofman 1990).

If the relationship between the projected seats and votes is classically proportional (Tufte 1973; see King 1989 for other definitions of fair), the relationship between seats and votes can be written in the following manner:

$$
\operatorname{Ln}(\mathrm{S} / 1-\mathrm{S})=\mathrm{B} \operatorname{Ln}(\mathrm{V} / 1-\mathrm{V})
$$

Equation 1 represents the logarithm of the cube law (Tufte 1973) which assumes the system is unbiased (intercept $=0$ ) and cube law proportional (B [swing ratio] $=3$ ). We can use the information to test how closely the projected seats-votes relationship for southern state legislative party systems approximates this model by estimating the following logit model:

$$
\operatorname{Ln}(\mathrm{S} / 1-\mathrm{S})=\operatorname{Ln}(\mathrm{a})+\mathrm{B} \operatorname{Ln}(\mathrm{V} / 1-\mathrm{V})
$$

where:

$$
S=\text { proportion of Democratic seats }
$$

$1-\mathrm{S}=$ proportion of Republican seats

$\mathrm{V}=$ proportion of Democratic votes

$1-\mathrm{V}=$ proportion of Republican votes 


$$
\begin{aligned}
\mathrm{B} & =\text { Swing Ratio (an exponent) } \\
\mathrm{a} & =\text { Bias parameter }
\end{aligned}
$$

In most studies, bias is defined as the proportion of seats over or under $50 \%$ for a party when its proportion of votes $=.5$. This can be computed in the following manner.

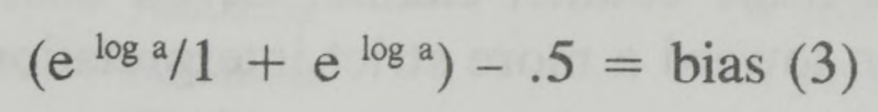

When "a" equals $0, \mathrm{e}^{\log \text { a }}$ equals 1 . This yields a bias of 0 . If the bias from equation 3 is a negative it indicates a bias against the Democrats (for example, -.02 means that when the Democratic proportion of the vote is .5 , they would obtain $48 \%$ of the seats (.48).) If the bias is positive, it indicates the system is skewed in favor of the Democrats (Campagna and Grofman 1990, 1245).

The main theoretical problem with this model is that it assumes a uniform partisan swing. King $(1989,797)$ notes that this assumption can be unrealistic, especially as one moves away from the competitive region around $50 \%$. However, Campagna and Grofman (1990) argue that for models that are attempting to ascertain partisan shifts, versus changes due to candidate specific variables, the uniform swing assumption is appropriate. In addition, in limiting the analysis to $\pm 10 \%$ of the actual votes-seats outcome, the analysis generally stays within the competitive region.

\section{Uncontested Districts}

A major question for this analysis is how to handle uncontested elections. This is not a trivial matter because of the large number of state legislative seats uncontested by Republicans (Aistrup 1990). For congressional studies, King and Gelman (1991) have estimated the percent of votes for uncontested incumbents based on prior voting in the districts. Because the Republican party does not have an extensive history of contesting elections in many of these uncontested districts, we lack a basis for reconstructing this vote. Thus, for any given election cycle uncontested elections are excluded.

Given that this analysis excludes uncontested districts, a strict interpretation of the findings limits its generalizability to only contested districts. It is important to note that many Republicans argue that gerrymandering has it most significant influence on uncontested districts. Their argument is that southern Democrats gerrymander district lines to minimize the threat of Republican candidates. Thus, this type of analysis leads to an underestimation of the extent of pro-Democratic bias in the district line boundaries. $^{6}$ 
An effective counter argument can be made by Democrats that it is difficult to gerrymander a minority party that rarely (if ever) contests state legislative elections (to gerrymander a minority political party, the majority party needs to perceive a threat to their rule from the minority party). Unfortunately, the lack of data precludes the possibility of empirically testing Republican claims and Democratic counter-claims. Given this, we choose to error of the side of caution toward a more strict interpretation of these findings.

It is important to note that while a Democratic basis for gerrymandering uncontested areas is difficult to define, this is not the case in those areas of the South were the GOP is active. Southern Democrats have every electoral reason to gerrymander areas where the Republicans contest and/or win elections. Thus, this analysis should enable an assessment of whether the GOP obtains a fair electoral shake in those areas where they are most likely to recruit state legislative candidates.

To broaden the scope of the analysis, it is necessary to compensate for the large number of uncontested seats as well as the staggered terms of many upper house state legislatures. Thus, this analysis compares the election results from the four year election cycle prior to redistricting to the results from the four year election cycle after the acceptance of the final redistricting plan for each state. This means for many states, the 1970 redistricting period compares the lower house results from the 1968-70 elections with those from the 1972-74 elections, while the 1980s redistricting period compares lower house results from the 1978-80 elections with those from $1982-84 .^{7}$

Some states sustained post redistricting court battles. Table 1 provides a listing of the states and the years in which there is a redistricting. Most of these court battles are the result of Voting Rights Act litigation. At issue in these cases was the creation of black majority districts or the dismantling of multimember districts, which generally have been found to dilute minority votes (Jewell 1982; Grofman et al. 1986). As noted above, the post redistricting period is defined as the four year election cycle after the acceptance of the final redistricting plan. This limits the analysis to an examination of the changes in the bias and swing ratio only within the context of the final redistricting plan. Also in this initial analysis, no distinction is made between SMDs and MMDs. ${ }^{8}$ The next section examines the differences for these types of districts.

Data for these analyses come from the "State Legislative Election Returns" (1992) data set made available through the ICPSR (8907). The election results for MMDs are coded in the manner suggested by Niemi et al. (1991). This procedure creates pseudo-single-member districts by 
Table 1. Electoral Institutions and Redistricting

\begin{tabular}{|c|c|c|}
\hline State & Cycle & Redistricting \\
\hline \multicolumn{3}{|l|}{ Lower House } \\
\hline Alabama & 4 year & 72,83 \\
\hline Arkansas & 2 year & 72,82 \\
\hline Florida & 2 year & 72,82 \\
\hline Georgia & 2 year & $72,74,82$ \\
\hline Mississippi & 4 year/odd & $71,75,79,81$ \\
\hline North Carolina & 2 year & 72,84 \\
\hline South Carolina & 2 year & $72,74,82$ \\
\hline Tennessee & 2 year & $72,74,84$ \\
\hline Texas & 2 year & $72,76,84$ \\
\hline Virginia & 2 year/odd & $71,73,81,82$ \\
\hline \multicolumn{3}{|l|}{ Upper House } \\
\hline Alabama & 4 year & 72,83 \\
\hline Arkansas & 4 year/stag & 72,82 \\
\hline Florida & 4 year/stag & 72,82 \\
\hline Georgia & 2 year & 72,82 \\
\hline Mississippi & 4 year/odd & $71,75,79,81$ \\
\hline North Carolina & 2 year & $72,84,86$ \\
\hline South Carolina & 4 year & 72,84 \\
\hline Tennessee & 4 year/stag & $72,74,80,84$ \\
\hline Texas & 4 year/stag & 72,84 \\
\hline Virginia & 4 year/odd & 71,83 \\
\hline \multicolumn{3}{|c|}{$\begin{array}{l}\text { stag: staggered elections } \\
\text { odd: elections held on odd election years }\end{array}$} \\
\hline
\end{tabular}

pairing the Democrats' highest vote-getter with the Republicans' lowest vote-getter. Through the process of elimination, this regimen rank orders candidates in descending/ascending fashion matching the election outcomes by voter preference and the extent of competitiveness in the MMD.

\section{Findings}

Table 2 begins the process of examining the swing ratio and bias in state legislative races for the lower and upper houses in the 1970s and 1980s. For your perusal, table 2 provides some basic election statistics. It is important to note that Mississippi and Virginia are excluded from the 


\section{Table 2. Percentage Democratic Vote and Control for Contested Seats Only}

\begin{tabular}{lcccccc}
\hline & \multicolumn{3}{c}{ Lower House } & \multicolumn{3}{c}{ Upper House } \\
Year & Mean \% & Control & $\mathrm{n}$ & Mean \% & Control & $\mathrm{n}$ \\
\hline Pre-1970s & 56.7 & 69.3 & 671 & 56.0 & 70.6 & 160 \\
Post-1970s & 56.4 & 66.0 & 938 & 55.0 & 67.6 & 188 \\
Pre-1980s & 56.0 & 68.3 & 837 & 58.4 & 73.5 & 264 \\
Post-1980s & 53.1 & 59.0 & 771 & 56.5 & 68.8 & 189
\end{tabular}

Total Vote: Percent Democratic Vote based on all votes cast.

Mean \%: Mean \% Democratic in each district.

Swing Ratio and Bias for Contested Seats Only Logit Analysis

\begin{tabular}{|c|c|c|c|c|c|c|c|c|}
\hline \multirow[b]{2}{*}{ Year } & \multicolumn{4}{|c|}{ Lower House } & \multicolumn{4}{|c|}{ Upper House } \\
\hline & a & Swing & Bias & $\mathrm{R}^{2}$ & $\mathrm{a}$ & Swing & Bias & $\mathrm{R}^{2}$ \\
\hline Pre-1970s* & $\begin{array}{l}-.02 \\
(.05)\end{array}$ & $\begin{array}{l}3.21 \\
(.04)\end{array}$ & -.005 & .99 & $\begin{array}{l}.10 \\
(.06)\end{array}$ & $\begin{array}{l}3.19 \\
(.06)\end{array}$ & .025 & .99 \\
\hline Post-1970s* & $\begin{array}{r}-.002 \\
(.03)\end{array}$ & $\begin{array}{l}2.58 \\
(.03)\end{array}$ & -.0005 & .99 & $\begin{array}{l}.05 \\
(.09)\end{array}$ & $\begin{array}{l}2.80 \\
(.08)\end{array}$ & .012 & .99 \\
\hline Pre-1980s & $\begin{array}{l}.07 \\
(.07)\end{array}$ & $\begin{array}{l}2.88 \\
(.07)\end{array}$ & .02 & .99 & $\begin{array}{l}-.05 \\
(.09)\end{array}$ & $\begin{array}{l}3.35 \\
(.08)\end{array}$ & -.012 & .99 \\
\hline Post-1980s** & $\begin{array}{c}.01 \\
(.02)\end{array}$ & $\begin{array}{l}2.74 \\
(.02)\end{array}$ & .003 & .99 & $\begin{array}{l}-.06 \\
(.07)\end{array}$ & $\begin{array}{l}2.71 \\
(.06)\end{array}$ & -.015 & .99 \\
\hline \multicolumn{9}{|c|}{$\begin{array}{l}\text { Standard errors in parentheses. } \\
\text { Bias }=\left(\mathrm{e}^{\log a} / 1+\mathrm{e}^{\log a}\right)-.5\end{array}$} \\
\hline
\end{tabular}

analysis of redistricting in the 1970 s period. Both states redistricted in 1971, the first year in which we have data on their state legislative contests. The bottom one-third of table 2 provides the estimates for the swing ratio and bias.

Bias

The findings are similar for the lower and upper houses. None of the coefficients measuring the extent of bias achieves statistical significance. 
Thus, the bias of the district lines in these areas of contested elections does not appear to overtly favor either party. Despite the lack of statistical significance, it is theoretically interesting to examine the signs and relative magnitudes of the bias coefficients.

Contrary to GOP claims, the signs of the coefficients indicate that the district lines have sometimes leaned toward the Republicans. This is the case in the early 1970s and it is also the case for upper house districts before and after the 1980s redistricting period. Table 2 also suggests that the redistricting process has not always worked to benefit the Democrats in these contested areas. In three out of the four redistricting periods, the bias shifts to a more favorable Republican orientation. Nonetheless, because the constants are insignificant, it suggests the bias of the party system in contested southern state legislative races is largely imperceptible. The findings in table 2 do not reinforce the GOP view that the system is so hopelessly tilted in the Democrats' favor, that the Republicans are unable to compete.

\section{Swing}

The swing ratio in this logit model represents an estimate of how closely the relationship between votes and seats equals three (Tufte 1973), the exponent in the cube law. In this analysis, we are interested in whether the swing ratio increases or decreases after redistricting. Table 2 shows that the upper and lower houses' swing ratios are similar and that the Democrats may be attempting, through the swing ratio, to insulate themselves from large partisan swings.

After redistricting in both decades, the swing ratio generally declines from over three to under three. The decline is most evident in lower house districts after the 1970 s redistricting. Here the swing ratio declines from 3.21 to 2.58 . A similar reduction in the swing ratio occurs in upper house districts in the $1980 \mathrm{~s}$ (3.35 to 2.71). After the 1980s redistricting, both chambers display a similar swing ratio of about 2.7 . These findings reinforce the notion that the Democrats use the redistricting process to insulate incumbents from shifts in aggregate voter preferences which might sweep many of them out the electoral door. A lower swing ratio tends to protect the status quo represented by a large number of Democratic incumbents. This initial analysis suggests that the redistricting process appears to insulate incumbents rather than building bias to gerrymander away Republican advances. 


\section{Single- and Multimember Districts}

The South is infamous for its myriad electoral arrangements, all of which were designed during the period of one-party Democratic domination. These arrangements, which include multimember districts with defined seats, multimember free-for-all districts, and floterial districts, or even some combination thereof, dilute the strength of minority factions by including them within a comprehensive multimember district with a large majority population. In theory these minority interests are unable to construct a majority to control any of the seats in the multimember district (Key 1949). Past studies show that multimember formats do hamper the ability of minorities to win (Jewell 1982; MacManus 1978, 1979; Grofman et al. 1986). Given this history, there is strong reason to suspect that the multimember format may be used as a means to dilute Republican strength within the context of the southern party system in the 1970s and 1980s. More importantly for this study, the elimination of multimember format, vis-à-vis the Voting Rights Act, should result in a shift in party system bias toward a more favorable Republican balance.

Table 3 examines the differences between the bias and the swing ratios for SMDs and MMDs. ${ }^{9}$ Importantly, to avoid potential problems with the VRA, the 1980s redistricting process eliminated most MMDs. The bias and swing ratio for MMDs in the 1980s is not particularly significant because of the small number of remaining MMDs (most of which are in North Carolina).

The bottom half of Table 3 shows that there was not a bias against the GOP in contested MMDs in the 1970s. Every constant (indicating the extent of bias in MMDs) failed to reach statistical significance. Nonetheless, the signs and relative magnitudes of the constants are theoretically interesting, because except for the post-1980 redistricting period in upper house districts, the bias in the MMDs is negligible or slightly favors the Republicans.

For SMDs, the bias generally favors the Democrats. This bias toward the Democrats achieves statistical significance for the upper house SMDs between the pre-1970s redistricting and the post-1970s redistricting (ranges between four and five percent). However, the bias toward the Democrats in upper house SMDs has declined. By the post-1980s period, after the elimination of most MMDs, the sign of the constant switches to favor the GOP and is statistically insignificant. This suggests that elimination of MMDs resulted in fairer upper house district lines. Perhaps the addition of former MMDs that are more favorably disposed toward the GOP served to counter balance Democratically biased SMDs. These findings provide limited 


\section{Table 3. Swing Ratio and Bias Controlling for Single- and Multimember Districts: Contested Seats Only}

\begin{tabular}{|c|c|c|c|c|c|c|}
\hline Year & $\begin{array}{c}\% \\
\text { Mean }\end{array}$ & $\begin{array}{l}\text { SMD } \\
\text { Control }\end{array}$ & $\mathrm{n}$ & $\begin{array}{c}\% \\
\text { Mean }\end{array}$ & $\begin{array}{l}\text { MMD } \\
\text { Control }\end{array}$ & $\mathrm{n}$ \\
\hline & \multicolumn{6}{|c|}{ Lower House } \\
\hline Pre-1970s & 55.2 & 57.1 & 191 & 57.2 & 74.2 & 480 \\
\hline Post-1970s & 56.5 & 62.9 & 533 & 56.9 & 70.1 & 405 \\
\hline Pre-1980s & 56.3 & 67.6 & 553 & 55.2 & 69.7 & 284 \\
\hline \multirow[t]{2}{*}{ Post-1980s } & 53.4 & 59.4 & 697 & 51.1 & 55.4 & 74 \\
\hline & \multicolumn{6}{|c|}{ Upper House } \\
\hline Pre-1970s & 56.0 & 69.1 & 81 & 56.1 & 72.2 & 79 \\
\hline Post-1970s & 55.3 & 67.4 & 95 & 54.7 & 67.7 & 93 \\
\hline Pre-1980s & 58.8 & 73.5 & 151 & 57.8 & 73.4 & 113 \\
\hline \multirow[t]{2}{*}{ Post-1980s } & 57.3 & 69.0 & 171 & 48.7 & 66.7 & 18 \\
\hline & \multicolumn{3}{|c|}{ Single-member } & \multicolumn{3}{|c|}{ Multimember } \\
\hline Year & $\mathrm{Sw}$ & ng Bias & $\mathrm{R}^{2}$ & a & Swing Bias & $\mathrm{R}^{2}$ \\
\hline
\end{tabular}

Swing Ratio and Bias for Lower House: Logit Analysis

$\begin{array}{lcccccccc}\text { Pre-1970s } & -.14 & 2.55 & -.035 & .97 & -.001 & 3.65 & -.0 & .99 \\ & (.12) & (.11) & & & (.07) & (.06) & & \\ \text { Post-1970s } & .006 & 2.21 & .002 & .99 & -.009 & 3.13 & -.002 & .99 \\ & (.05) & (.04) & & & (.05) & (.04) & & \\ \text { Pre-1980s } & .08 & 2.53 & .02 & .98 & .07 & 3.71 & .02 & .99 \\ & (.08) & (.07) & & & (.04) & (.04) & & \\ \text { Post-1980s } & .02 & 2.62 & .005 & .99 & .00 & 3.58 & 0 & .99 \\ & (.02) & (.02) & & & (.10) & (.09) & & \end{array}$

Swing Ratio and Bias for Upper House: Logit Analysis

$\begin{array}{lcccccccc}\text { Pre-1970s } & .22 & 2.44 & .05 & .98 & -.03 & 4.09 & -.007 & .97 \\ & (.10) & (.08) & & & (.16) & (.14) & & \\ \text { Post-1970s } & .18 & 2.08 & .04 & .98 & -.09 & 3.65 & -.02 & .98 \\ & (.08) & (.07) & & & (.11) & (.10) & & \\ \text { Pre-1980s } & .07 & 2.66 & .02 & .98 & -.22 & 4.66 & -.05 & .96 \\ & (.06) & (.05) & & & (.25) & (.22) & & \\ \text { Post-1980s } & -.06 & 2.70 & -.015 & .99 & .16 & 4.33 & .04 & .91 \\ & (.08) & (.07) & & & (.34) & (.31) & & \end{array}$

Standard errors in parentheses.

Bias $=\left(\mathrm{e}^{\log \text { a }} / 1+\mathrm{e}^{\log a}\right)-.5$ 
support for the idea that the GOP uses the provisions of the Voting Rights Act to create SMDs that are less favorably disposed to the Democrats.

Interestingly, the bias toward the Democrats in lower house SMDs does not achieve statistical significance. Moreover, the signs and magnitudes of the constants indicate that the extent of bias is largely imperceptible throughout the periods of study. Taken together, these findings suggest that after the 1980s redistricting, there is not a substantial bias in contested southern state legislative districts.

Unfortunately for the Republicans, the swing ratio is much lower in SMDs than in MMDs. In most cases, the swing ratio for MMDs is over 3.5, whereas for SMDs, it is less than 2.7. This suggests that the movement toward the SMD format, precipitated by the Voting Rights Act, tends to favor the Democrats, because SMDs have a lower swing ratio and the Democrats have more incumbents to protect. As MMDs have been eliminated, there has been a decline in the overall swing ratio for the entire system.

Table 3 suggests that the elimination of MMDs resulted in a partisan wash. Democrats gained because of the lower swing ratio. However, to the extent that the Republicans make slow progress in electing its members, the low swing ratio in SMDs protects their incumbents as well as the Democrats. The Republicans gained because of the diminished pro-Democratic bias in upper house SMDs. However, this came at the expense of losing pro-Republican bias in contested MMDs.

These findings supplement and potentially alter the interpretation of traditional analyses concerning the influence of MMDs on Republican prospects. For example, Bullock and Gaddie (1993) tracked the lineage of districts that switched from multimember to single-member districts in Florida, South Carolina and North Carolina. While their findings varied depending on the state and chamber, the upshot of their analysis is that the elimination of MMDs helped the GOP elect more candidates than they otherwise would have. The analysis here would seem to suggest that Republican gains are as much a function of changing political circumstances as changing institutional arrangements.

In a couple of respects, analyses like Bullock and Gaddie's have some advantages over this analysis. First, their analysis technique compares the actual election results (as compared to a hypothetical model) before and after the switch from MMDs to SMDs. Second, their analysis is not limited to examining only contested elections. However, analyses like Bullock and Gaddie's suffer because they attempt to compare one decade's political results with another decade's political results. As Bullock and Gaddie note, it is difficult to discern whether the GOP gains are due to changing political or institutional conditions $(1993,156)$. 


\section{Florida and South Carolina}

To gain some degree of comparability with Bullock and Gaddie's findings, we compare the bias and swing ratio for Florida's and South Carolina's multimember state senate districts that became single-member districts in the 1980s. North Carolina is excluded from this analysis because we do not have state legislative election returns for North Carolina beyond 1984. Bullock and Gaddie's findings suggest that the switch in Florida resulted in some minor long-term gains for Republicans after some initial losses in 1982. The switch in South Carolina was followed by Republican gains in both 1984 and $1988(1993,158)$.

Florida and South Carolina have differing types of multimember formats. Most of Florida's multimember districts are multimember with alternating positions. The elections for each position in the multimember district alternates between election years. In South Carolina, all but one of the districts are multimember districts with positions. All the positions are contested in the same election. Voters in these MMDs choose between a number of mutually exclusive paired-off candidates. In Florida, this occurs only in the election immediately following redistricting.

To increase the number of contested elections for each state (providing the basis for the hypothetical models), we compare the election results from 1972 to 1980 with the results from 1982 to 1988 . Because the number of valid elections are nonetheless small in each state, we change the range for the hypothetical seats/votes model to examine the range between $\pm 7 \%$ from the actual seats/votes outcome. This change avoids some outliers that occur on the extremes of the hypothetical model due to the small number of cases. ${ }^{10}$ Even with these precautions, it is important to note that the reliability of this method of analysis declines as the number of valid cases becomes small.

The analysis shown in Table 4, provides some support for our previous analysis. The Republicans did not profit in the manner that one might reasonably expect from the switch from MMDs to SMDs. The bias parameter for MMDs in Florida in the late 1970s is -.02 , while in South Carolina it is -.10 . This shows that the Republicans in these contested MMDs had an advantage over the Democrats if they could obtain enough votes to overcome their other problems. After the change to SMDs, the extent of bias toward the Republicans in converted SMDs drops to .003 in Florida, and -.005 in South Carolina. 


\section{Table 4. The Conversion of Multimember Districts in Florida and South Carolina}

\begin{tabular}{|c|c|c|c|c|c|c|c|c|}
\hline \multirow[b]{2}{*}{ Year } & \multicolumn{4}{|c|}{ Florida Upper House } & \multicolumn{4}{|c|}{ South Carolina Upper House } \\
\hline & a & Swing & Bias & $\mathrm{R}^{2}$ & a & Swing & Bias & $\mathrm{R}^{2}$ \\
\hline $\begin{array}{l}\text { Multimember } \\
\text { Pre-1980s }\end{array}$ & $\begin{array}{l}-.10 \\
(.08)\end{array}$ & $\begin{array}{l}3.26 \\
(.11)\end{array}$ & -.02 & .98 & $\begin{array}{l}-.40 \\
(.17)\end{array}$ & $\begin{array}{l}4.14 \\
(.25)\end{array}$ & -.10 & .96 \\
\hline $\begin{array}{l}\text { Multimember } \\
\text { Shifted to SMD } \\
\text { Post } 1980 \text { s }\end{array}$ & $\begin{array}{c}.01 \\
(.24)\end{array}$ & $\begin{array}{l}4.26 \\
(.36)\end{array}$ & .003 & .92 & $\begin{array}{l}-.02 \\
(.07)\end{array}$ & $\begin{array}{l}2.70 \\
(.11)\end{array}$ & -.005 & .98 \\
\hline $\begin{array}{l}\text { Standard errors } \\
\text { Bias }=\left(\mathrm{e}^{\log a} / 1\right.\end{array}$ & $\begin{array}{l}\text { n paren } \\
+\mathrm{e}^{\log \varepsilon}\end{array}$ & $\begin{array}{l}\text { eses. } \\
-.5\end{array}$ & & & & & & \\
\hline
\end{tabular}

The findings for the swing ratios in Florida do not conform with the overall analysis. In Florida, the swing ratio for MMDs is 3.26 in the 1970s. After the conversion to SMDs, the swing ratio increases to 4.26. The findings for South Carolina conform more closely to our overall analysis. The swing ratio for MMDs in the 1970 s is a robust 4.14. In the 1980 s, after the conversion to SMDs, the swing ratio drops to 2.70 .

The higher swing ratio in Florida resulting from the conversion of MMDs to SMDs is an interesting finding. We speculate that this higher swing ratio is more than likely a product of the interaction between Florida's rapidly changing demography and the smaller district sizes. Larger MMDs mute the political influences of demographic changes, because the size of the district overwhelms these changes. In smaller SMDs, the political influences of demographic changes have a more concentrated effect, because the size of the district is not as likely to overwhelm the influence of the new population. This perhaps leads to a more volatile electoral environment and a higher swing ratio.

In Florida, Republicans have fair district lines that do not favor either party. However, unlike South Carolina, the swing ratio is high meaning that if the Republicans could have managed a large electoral tide in their favor in the $1980 \mathrm{~s}$, there was the possibility for sweeping gains. The turbulent electoral situation in the Florida upper house conforms to this high swing ratio.

The implication of these findings for Bullock and Gaddie's (1993) results in Florida is that the changes in Florida's partisan representation are related to the large swing ratio and shifting political tides. This point supplements their conclusion that redistricting in the 1980s did not result in 
significant Republican gains. From their perspective, "smaller concentrations of blacks" in Florida led to Democrats being able to "fashion districts favorable to their party." (Bullock and Gaddie 1993, 159) To the extent that the swing ratio increased in Florida, the structure of the districts may have enhanced (or hurt as in the case of 1982) the Republicans' chances of winning some seats.

In South Carolina, the substantial GOP gains in the upper chamber may be more related to shifting political tides than shifting political districts. This finding runs counter to Bullock and Gaddie's (1993) results that suggest South Carolina Republicans fared better after redistricting in the 1980s. Table 4 shows that when the change from MMDs to SMDs occurred, the Republicans lost the bias that leaned in its favor, and the large swing ratio, which might have helped them in volatile electoral periods.

Comparing the electoral results of the upper and lower chambers of South Carolina buttresses our case that political conditions, rather than district configuration, explain the GOP gains in South Carolina. Significantly, South Carolina's lower house converted to SMDs in the 1970s. In the lower house, the GOP started the 1980 s with $13 \%$ of the seats. In the upper house, they started the decade with $11 \%$ of the seats (before redistricting). After redistricting in 1982, the GOP increased their representation in the lower house to only $16 \% .{ }^{11}$ After Reagan's landslide 1984 victory, this percentage increased to $22 \%$. In the 1984 upper house elections (the first election after redistricting for the upper house), the Republicans increased their representation to an identical $22 \%$.

Despite this evidence suggesting that shifting political conditions have led to the GOP gains, this conclusion is tempered by a couple of points. First, this analysis examines a small number of contested elections in the 1970s (less than 40), which can have a significant effect on the results of the hypothetical model. Second, South Carolina Republicans may have refocused where they contest elections in the 1980 s based on the new realities of district line boundaries. Bullock and Gaddie's (1993) paper shows evidence that this did occur. Nonetheless, the results presented here suggest that the advantages that the GOP perceived in the new district lines may have been as much psychological as factual. Perceiving a new advantage, Republican candidates ran for office when they may not have otherwise. In 1980 , Republicans contested only $33 \%$ of state senate seats, whereas in 1984, they contested $59 \%$.

\section{Conclusion}

In conclusion, these findings suggest three important points. First, the extent of bias toward the Democratic party in contested southern state 
legislative seats is not great. On the whole, the amount of bias in both state legislative chambers is at times imperceptible. Second, the Democrats have been using the redistricting process to lower the responsiveness of the system to changes in vote share. The swing ratio for contested seats tends to be under three for SMDs (excluding Florida). Finally, the switch from MMDs to SMDs appears to be a political wash. The resulting SMDs do not have a bias favoring either party while Democratic incumbents (and Republicans) gain because of the lower swing ratio.

On the practical political side, the significance of these findings is that if the Republicans are seeking to blame the redistricting process for their past inability to win state legislative elections in the South, it is time to begin searching for a new excuse. Only lower house SMDs in the pre-1980s period show significant levels of bias toward the Democrats. With the redistricting in the $1980 \mathrm{~s}$, this Democratic bias was erased. ${ }^{12}$ The one aspect of contested district line boundaries that is retarding GOP progress is the declining swing ratio. Because a lower swing ratio favors incumbents, it tends to protect the Democratic status quo.

\section{NOTES}

Data for this paper are supplied by the ICPSR. The ICPSR bears no responsibility for the interpretations of the data in this paper.

${ }^{1}$ Louisiana is excluded because of the lack of available data for its state legislative elections over the period covered in this analysis.

${ }^{2}$ Telephone interview conducted by Joseph Aistrup on 12-15-1992.

${ }^{3}$ Telephone interview conducted by Joseph Aistrup on 2-15-1987.

${ }^{4}$ The explicit assumption of those who believe gerrymandering is important, is that a constituency that is favorably tilted toward one party, will remain favorably disposed toward that party in a new district. This assumption is questioned by the candidatecentered literature (Jacobson 1990). This literature stresses that voters have become increasingly attached to candidates and unattached from parties. Thus, when a constituency is placed within the confines of a different jurisdiction and candidate, its aggregate partisan voting patterns are not predictable. The up-shot of this line of reasoning is that gerrymandering has little or no effect.

${ }^{5}$ There is controversy concerning the measurement of a party's share of two-party vote. For more on this controversy see Jacobson (1990, 83-94).

${ }^{6}$ In our estimation this argument rings hollow, because it hinges on the myth of a subnational Republican threat (i.e. substantial subnational Republican enclaves-party activists and voters) in these uncontested Republican areas. Except for national voting patterns showing a tendency of southern whites to vote for Republican candidates (remember, even in 1980 this was not a pattern that was carved in stone), there is little evidence supporting the idea that there was an emerging subnational Republican threat in the early 1970s or early 1980s. While the Republican National Committee sponsored a program to elect state legislative candidates in 1980 , this program centered its efforts 
in urban areas across the South-the areas where southern Republicans have traditionally contested elections (Aistrup 1990).

Unfortunately for the Republicans' argument, numerous analyses have shown that since the turn of the century, the southern Democrats have dominated whole regions of the South (Key 1949; Lamis 1988; Aistrup 1990; Jewell 1967). Up to the early 1980s, subnational Republican activity was limited to specific geographic areas-urban and mountain Republican areas. Without a subnational Republican threat in many areas, on what basis did the Democrats gerrymander away potential Republican candidates? What Democratic precautions need to be taken for an unmaterialized subnational Republican threat? Republicans answer that the basis for gerrymandering may be national and statewide voting patterns. However, this represents more conjecture than proven fact.

${ }^{7}$ This leads to the situation where in lower house races (in most states, lower house districts are contested every two years) some Republican incumbent districts are double counted. To the extent that these districts are theoretically less biased toward the Democrats, this acts to depress any pro-Democratic bias in the electoral system.

${ }^{8}$ We treat multimember districts as Niemi et al. (1991) suggest, by pairing the top vote-getter from one party with the lowest vote-getter from the other party. Through the process of elimination, this procedure is then repeated for all available seats in a multimember district.

${ }^{9}$ For this analysis we combine the different types of MMDs. Most of the MMDs were either multimember with positions or multimember-alternating. We did not find a significant difference between these types of districts. Floterial districts are less numerous and often uncontested, thus there was a limited sample of contested elections for creating the seats/votes relationship.

${ }^{10}$ Because of the high percentage of votes obtained by the Democrats in South Carolina in the $1970 \mathrm{~s}$, we adjusted the seats/votes relationship to range from $-10 \%$ to $+5 \%$ of the actual outcome. This alteration allows the analysis to examine the hypothetical point where the Democrats' proportion of votes is .5.

${ }^{11}$ We are willing to concede that the creation of additional black majority districts in the lower house may have led to this slight increase in Republicans.

${ }^{12}$ These findings buttress the type of argument made by Jacobson (1990) at the congressional level. The findings here lend credence to the idea that Republican failure to translate their presidential majority into a greater presence in southern state legislatures is rooted in political reasons versus the Democrats' stacking the institutional deck against them. This conclusion, however, must be tempered because of the limited scope of this analysis-contested districts.

\section{REFERENCES}

Abramowitz, Alan I. 1983. Partisan Redistricting and the 1982 Congressional Elections. Journal of Politics 45:767-70.

Aistrup, Joseph A. 1990. Republican Contestation of U.S. Senate Elections in the South. Legislative Studies Quarterly 15:227-45.

Ansolabehere, Stephen, David Brady, and Morris Fiorina. 1988. The Marginals Never Vanished? Working Papers in Political Science P-88-1. The Hoover Institution, Stanford University. 
Black, Earl and Merle Black. 1987. Politics and Society in the South. Cambridge: Harvard University Press.

Bullock, Charles S. III. 1989. Creeping Realignment in the South. In The South's New Politics: Realignment and Dealignment, ed. Swansbrough, R.H. and D.M. Brodsky, Columbia, SC: University of South Carolina Press.

Bullock, Charles S. III and Ronald K. Gaddie. 1993. Changing from Multimember to Single-member Districts: Partisan, Racial, and Gender Consequences. State and Local Government Review 25:155-63.

Butler, David. 1953. The Electoral System in Britain 1918-1951. London: Oxford University Press.

Campagna, Janet and Bernard Grofman. 1990. Party Control and Partisan Bias in 1980s Congressional Redistricting. Journal of Politics 52:1242-57.

Grofman, Bernard. 1983. Measures of Bias and Proportionality in Seats-Votes Relationships. Political Methodology 9:295-327.

Grofman, Bernard. 1990. Toward a Theory of Gerrymandering: Bandemer and Thornberg. In Political Gerrymandering and the Courts. New York: Agathon Press.

Grofman, Bernard, M. Migalski, and N. Noviello. 1986. Effects of Multimember Districts on Black Representation in State Legislatures. Review of Black Political Economy 14:65-78.

Inter-university Consortium of Political and Social Research. 1992. State Legislative Election Returns in the United States: 1968-1989. Fourth ICPSR ed. Ann Arbor, MI: ICPSR.

Jacobson, Gary. 1990. The Electoral Origins of Divided Government. Boulder, CO: Westview Press.

Jewell, Malcolm. 1982. Representation in State Legislatures. Lexington: University Press of Kentucky.

Key, V.O., Jr. 1949. Southern Politics in the State and Nation. New York: Knopf.

King, Gary. 1989. Representation through Legislative Redistricting: A Stochastic Model. American Journal of Political Science 33:787-824.

King, Gary and Robert X. Browning. 1987. Democratic Representation and Partisan Bias: A Model of Seats and Votes for American Congressional Elections. American Political Science Review 81:1251-73.

King, Gary and Andrew Gelman. 1991. Systemic Consequences of Incumbency Advantage in U.S. House Elections. American Journal of Political Science 35:110-38.

Lamis, Alexander. 1988. The Two-Party South. New York: Oxford University Press.

Lowenstein, Daniel. 1990. Bandemer's Gap: Gerrymandering and Equal Protection. In Political Gerrymandering and the Courts. New York: Agathon Press.

MacManus, Susan. 1978. City Council Election Procedures and Minority Representation. Social Science Quarterly 59:153-61.

1979. At Large Elections and Minority Representation: An Adversarial Critique. Social Science Quarterly 60:338-40.

Niemi, Richard G., Simon Jackman, and Laura R. Winsky. 1991. Candidates and Competitiveness in Multimember Districts. Legislative Studies Quarterly 16:91110.

Tufte, Edward. 1973. The Relationship Between Seats and Votes in Two-Party Systems. American Political Science Review 67:540-54. 